C

International Journal of

Educational Psychology
Hipatia Press

www.hipatiapress.com

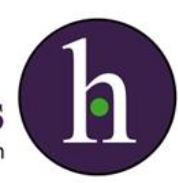

Instructions for authors, subscriptions and further details:

http://ijep.hipatiapress.com

\title{
Students' Attitude and Motivation in Bilingual Education
}

Beatriz Calderón Jurado ${ }^{1}$ \& Cristina Morilla García ${ }^{1}$

1) University of Cordoba, Spain

Date of publication: October $24^{\text {th }}, 2018$

Edition period: October 2018 - February 2019

To cite this article: Calderón Jurado, B., \& Morilla García, C. (2018). Students' attitude and motivation in bilingual education International Journal of Educational Psychology, 7(3), 317-342. doi: 10.17583/ijep.2018.3558

To link this article: http://dx.doi.org/10.17583/ijep.2018.3558

\section{PLEASE SCROLL DOWN FOR ARTICLE}

The terms and conditions of use are related to the Open Journal System and to Creative Commons Attribution License (CC-BY). 


\section{Students' Attitude and Motivation in Bilingual Education}

Beatriz Calderón Jurado, Cristina Morilla García

University of Cordoba

\section{Abstract}

Motivation and attitude are two affective factors that can determine the success of students' learning. The objective of this study is to investigate how attitude and motivation affect students in bilingual teaching programs. This study comprised a total of 159 Spanish students and was conducted in the third and fourth year of primary education in which the level of the L2 corresponds to A2.1 of the CEFR (Common European Framework of Reference). The study involved two schools in the province of Cordoba (Andalusia) in which CLIL (Content and Language Integrated Learning) program is implemented. A quantitative methodology has been used whereby students' attitude and motivation have been analysed through a questionnaire. The results show that although motivation and attitude are positive in science subjects within the bilingual program, it is necessary to pay greater attention to diversity and to the different pace of learning among students.

Keywords: attitude; motivation; bilingual program; CLIL; science subjects. 


\section{Actitud y Motivación de los Estudiantes en la Educación Bilingüe}

Beatriz Calderón Jurado, Cristina Morilla García University of Cordoba

\section{Resumen}

La motivación y la actitud son dos factores afectivos que pueden determinar el éxito del aprendizaje de los alumnos. El objetivo de este estudio es indagar cómo la actitud y la motivación afectan a los estudiantes con respecto al programa bilingüe. Esta investigación comprende un total de 159 estudiantes españoles y ha tenido lugar en el tercer y cuarto año de educación primaria en el que el nivel de la L2 corresponde al A2.1 del MCER (Marco Común Europeo de Referencia). El estudio se ha realizado en dos centros de la provincia de Córdoba (Andalucía) en los que el programa AICLE (Aprendizaje Integrado de Contenidos e Idiomas) está implementado. Se ha aplicado una metodología cuantitativa en la que se ha analizado la actitud y la motivación de los estudiantes mediante un cuestionario. Los resultados muestran que aunque la motivación y la actitud son positivas en las asignaturas de ciencias dentro del programa bilingüe, es necesario reforzar la atención a la diversidad y los diferentes ritmos de aprendizaje.

Palabras clave: actitud; motivación; programa bilingüe; CLIL; asignaturas de ciencias. 
owadays, English is a language that is spoken around the world, according to Broughton, Brumfit, Pincas and Wilde (2002), there are 300 million native speakers in every continent of the globe. In addition, there are over 250 million speakers who use English as a second language in their daily life: it is the language of mass media, official institutions and the language of the commercial and industrial organizations. Consequently, it has become a necessity to learn English at school. The target language has been integrated into the Spanish education system in such a way that educational programs have become bilingual in nature. These programmes require students to become familiar with the foreign language while learning subjects such as science, art and physical education among others. Therefore, affective factors such as attitude and motivation can play an important role in the process of acquiring the second language. According to Latchanna and Dagnew (2009), attitude is seen as a relevant concept for understanding human behaviour and is defined as a mental state which includes feelings and beliefs. Beliefs are connected with success in language lessons. Following Lennartsson (2008), motivation and the desire to learn a second language are considered more relevant factors than social ones; positive attitudes among students tend to raise students' motivation. In fact, a good teacher should tap into the sources of intrinsic motivation and try to find ways to relate them to external motivation factors. Likewise, it is appropriate to identify learners' objectives and needs in order to develop accurate motivational strategies. Appropriate attitudes and feelings are needed to raise the competence of students in language learning lessons. The aim of this research is to investigate the value of affective factors such as attitude and motivation in bilingual education.

\section{The competence of attitude and motivation in bilingual education}

Learning a foreign language is a complex process in which several factors are involved. The process of learning a foreign language not only implies a cognitive approach. Rather, there are several factors which influence the learning of a foreign language, such as the context, learning achievement, intelligence, age, etc. and affective factors as attitude, motivation and anxiety. Focusing on attitude, Gardner and Lambert (1972) demonstrated 


\section{Calderón Jurado \& Morilla García - Bilingual Education}

that the ability of students to achieve proficiency in a second language is not only influenced by mental competence or language skills, but also on the learners' attitudes and perceptions about the target language. Furthermore, Victori and Lockhart (1995) asserted that students' negative beliefs are related to class anxiety, low cognitive achievement and negative attitudes. Following this line, Reid (2003) stated that attitude is related to the achievement of the student due to the fact that learning a foreign language implies not only the intellectual capacity of the learner but also the attitude towards language learning. In addition, Montano and Kasprzyk (2008) assert that:

Attitude is determined by the individual's belief about outcomes or attributes of performing the behaviour (behavioural beliefs), weighted by evaluations of these outcomes or attributes. Thus, a person who holds strong beliefs that positively valued outcomes will result from performing the behaviour. Conversely, a person who holds strong beliefs that negatively valued outcomes will result from the behaviour will have a negative attitude (p.71).

The same happens with motivation. In fact, there are several models based on motivation and language learning. Gardner and Lambert (1972) established the socio-psychological model: for them, there are two kinds of motivation: the first kind is integrative motivation which refers to learners' willingness to learn the language in order to take part in the community which speaks that language. The second kind is instrumental motivation, which deals with learners' desire to acquire foreign language proficiency for practical purposes. Another framework concerns Self-Determination Theory (Deci \& Ryan, 1985; Noels, 2001; Noels, Pelletier, Clément, \& Vallerand, 2003). This theory covers also two kinds of motivation: extrinsic motivation, which deals with external factors that influence the learning of a foreign language; and intrinsic motivation, which refers to the interest of learners generated by doing an activity. According to Dörnyei (1998), motivation affects success rate of learners. In fact, if motivation is lacking, even the most remarkable learners with the most impressive abilities are unable to achieve a long-term goal. Likewise, motivation plays an important role in the acquisition of a foreign language as it is a communication coding taught at school. It is an integral part of individual identities, as well as being a form of social organisation that is embedded in a culture community. 


\section{Content Language and Integrated Learning (CLIL) in Andalusia}

According to García (2009) teachers have a responsibility to educate students as responsible citizens who are prepared for the globalized world. For these reasons it is essential to implement bilingual education in Spain and to follow a suitable approach for the acquisition of the lingua franca. According to Peter Mehisto (2012), and based on the definition provided by Maljers, Marsh and Wolff (2007), CLIL is a dual-focused teaching and learning approach in which the L1 and the additional language or two are used for promoting both content mastery and language acquisition to predefined levels. Several subjects can be taught through the CLIL program depending on the qualification of teachers. Nowadays the focus is on history, geography, science and social sciences specifically in Secondary Education. According to Pérez-Cañado (2012), the materials used for these subjects can be adapted from authentic sources or designed with the assistance of Information and Communication Technology (ICT). Coyle (2010) established the 4C Framework, which are, according to him, the four basic ingredients for the CLIL classroom: content, communication, culture and cognition.

\section{Method}

\section{Objectives and Research Questions}

The aim of this research is to investigate specific research questions concerning the attitude and motivation of students towards their school's bilingual program, more specifically, with regards to science subjects. To do so, a quasi-experimental design has been developed using a questionnaire. According to Campbell and Stanley (1963) a quasi-experimental design is made from situations which already exist in the real world and are more representative in an educational context. It is difficult to control many of the variables and the groups cannot be modified. Specific objectives, attitude and motivation have been evaluated in relation to the following research questions:

1. Are students feeling motivated with the bilingual program at school?

2. Is this bilingual program improving their attitude towards English? 
3. Do children value the fact that they can learn English in subjects such as science?

4. How do they feel when the teacher makes use of the second language in the classroom?

\section{Contextualization and Data Gathering}

The present study was carried out in two different public education schools of primary education. The first one is the CEIP 14001682, which is situated in center Córdoba. The second one is the CEIP 14004075, which is situated in a town in northern Córdoba. Number of students and schedules for bilingual classes in every school are presented in table 1 and table 2.

Table 1

Number of students and schedule CEIP 14001682

\begin{tabular}{llc}
\hline Groups & Schedule & Number of students \\
\hline 3rd A & 1rst TIME & 26 \\
4th A & 2nd TIME & 24 \\
4th B & 3rd TIME & 22 \\
4th D & 4th TIME & 24 \\
3th B & 5th TIME & 26 \\
\hline
\end{tabular}

Table 2

Number of students and schedule CEIP 14004075

\begin{tabular}{ccc}
\hline Groups & Schedule & Number of students \\
\hline 3rd A & 4th TIME & 21 \\
4th A & 5th TIME & 16 \\
\hline
\end{tabular}

The instrument employed for data collection was a questionnaire, named "Attitude and motivation in bilingual education within the primary school". 
This instrument was revised for three experts specialized in the subject of the area in order to validate it. The Delphi method was used: a) one EFL professor, b) one applied linguistics university lecturer, and c) one computer engineer specialized in e- learning. The questionnaire is composed of 21 questions divided into four dimensions: students' motivation towards the bilingual program, students' attitude towards the bilingual program, assessment of students about learning English in subjects such as sciences, and the use of the second language in the classroom. Each item is rated on a 5-point Likert scale ranging from 1 (strongly agree) to 5 (strongly disagree). The data obtained is quantitative in nature; however, as responses were descriptive, qualitative data is also offered. Besides, Alpha's Cronbach has been used, which demonstrates the internal reliability of the questionnaire (See table 3). This statistical method gives us information about "the degree to which the items in a scale measure similar characteristics" (Pérez-Paredes \& Martínez-Sanchez, 2000-2001, p. 341). The more the results are approximated to .1, the more reliable the questionnaire; the developed questionnaire yields an internal consistency of .726, which means that the reliability of the questionnaire is acceptable.

Table 3

Reliability statistics

\begin{tabular}{ccc}
\hline & $\begin{array}{c}\text { Alpha's Cronbach } \\
\text { based on } \\
\text { Alpha's }\end{array}$ & \\
standardized \\
Cronbach & items & N of items \\
\hline, 691 &, 726 & 23 \\
\hline
\end{tabular}

\section{Results}

The results and data analyses presented below are grouped into four dimensions in order to answer the research questions respectively.

The first dimension addresses students' motivation towards the bilingual program, and the obtained results respond to the first research question. 
Table 4

Valid percentage questionnaires' results, question 1

"Students are pleased when using the foreign language among themselves".

\begin{tabular}{|c|c|c|c|c|c|}
\hline & & Frequency & Percentage & $\begin{array}{c}\text { Valid } \\
\text { percentage }\end{array}$ & $\begin{array}{c}\text { Accumulated } \\
\text { percentage }\end{array}$ \\
\hline \multirow[t]{6}{*}{ Valid } & I agree completely & 116 & 73,0 & 73,0 & 73,0 \\
\hline & I agree & 21 & 13,2 & 13,2 & 86,2 \\
\hline & I do not know & 17 & 10,7 & 10,7 & 96,9 \\
\hline & I disagree & 3 & 1,9 & 1,9 & 98,7 \\
\hline & I disagree completely & 2 & 1,3 & 1,3 & 100,0 \\
\hline & Total & 159 & 100,0 & 100,0 & \\
\hline
\end{tabular}

As it can be shown in table 4, children demonstrate a positive attitude towards speaking English among themselves; additionally, in table 5, it is observed that the use of the ICT in lessons makes students appreciate learning the lingua franca. Nowadays ICTs are a great tool for teaching English. There are many applications and games that help students to learn English and improve their attitude and motivation towards the second language.

Table 5

Valid percentage questionnaires' results, question 2

"Students value the use of ICTs for learning contents".

\begin{tabular}{llllll}
\hline & & & Valid & Accumulated \\
Valid & I agree completely & 115 & 72,3 & 72,3 & 72,3 \\
& I agree & 32 & 20,1 & 20,1 & 92,5 \\
& I do not know & 8 & 5,0 & 5,0 & 97,5 \\
& I disagree & 1 &, 6 &, 6 & 98,1 \\
I disagree completely & 3 & 1,9 & 1,9 & 100,0 \\
Total & 159 & 100,0 & 100,0 & \\
\hline
\end{tabular}


Table 6

Valid percentage questionnaires' results, question 3

"The use of the mother tongue in lessons makes students feel confident when they are unable to understand the concept in English".

\begin{tabular}{|c|c|c|c|c|c|}
\hline & & Frequency & Percentage & $\begin{array}{l}\text { Valid } \\
\text { percentage }\end{array}$ & $\begin{array}{l}\text { Accumulated } \\
\text { percentage }\end{array}$ \\
\hline \multirow[t]{6}{*}{ Valid } & I agree completely & 101 & 63,5 & 63,5 & 63,5 \\
\hline & I agree & 15 & 9,4 & 9,4 & 73,0 \\
\hline & I do not know & 8 & 5,0 & 5,0 & 78,0 \\
\hline & I disagree & 14 & 8,8 & 8,8 & 86,8 \\
\hline & I disagree completely & 21 & 13,2 & 13,2 & 100,0 \\
\hline & Total & 159 & 100,0 & 100,0 & \\
\hline
\end{tabular}

Furthermore, in table 6 it is exposed that more than half of students $(63,5 \%)$ completely agree, saying that they feel more confident when the teacher uses the mother tongue to clarify something they have not understood in English. It may be that sometimes students are unable to properly understand vocabulary in English and that they need further explanations. In addition to that, as it is analyzed in table 7, 61,6\% of students completely agree considering English useful as a valuable tool for the future, and, this idea has a positive effect on their attitude and motivation.

Table 7

Valid percentage questionnaires' results, question 4 "Students approve learning science subjects within the bilingual program".

\begin{tabular}{llllll}
\hline & & & Valid & Accumulated \\
Valid & I agree completely & 98 & 61,6 & 61,6 & 61,6 \\
& I agree & 21 & 13,2 & 13,2 & 74,8 \\
& I do not know & 18 & 11,3 & 11,3 & 86,2 \\
& I disagree & 6 & 3,8 & 3,8 & 89,9 \\
I disagree completely & 16 & 10,1 & 10,1 & 100,0 \\
Total & 159 & 100,0 & 100,0 & \\
\hline
\end{tabular}




\section{Calderón Jurado \& Morilla García - Bilingual Education}

Table 8

Valid percentage questionnaires' results, question 5

"Students value the possibility of practising English at home with their parents".

\begin{tabular}{llllll}
\hline & & & Valid & Accumulated \\
Valid & I agree completely & 113 & 71,1 & 71,1 & 71,1 \\
& I agree & 17 & 10,7 & 10,7 & 81,8 \\
& I do not know & 16 & 10,1 & 10,1 & 91,8 \\
& I disagree & 6 & 3,8 & 3,8 & 95,6 \\
I disagree completely & 7 & 4,4 & 4,4 & 100,0 \\
Total & 159 & 100,0 & 100,0 & \\
\hline
\end{tabular}

Finally, it needs to be mentioned that table 8 is representative by showing that $71,1 \%$ of learners agree completely and appreciate their parents' help with their English homework. This constitutes great scaffolding by parents and increases children's motivation to continue learning English.

The second dimension that is analyzed is the students' attitude towards the bilingual program that addresses the second research question of the study.

\section{Table 9}

Valid percentage questionnaires' results, question 6

"Students feel satisfaction when the teacher uses the lingua franca".

\begin{tabular}{|c|c|c|c|c|c|}
\hline & & Frequency & Percentage & $\begin{array}{l}\text { Valid } \\
\text { percentage }\end{array}$ & $\begin{array}{l}\text { Accumulated } \\
\text { percentage }\end{array}$ \\
\hline \multirow[t]{6}{*}{ Valid } & I agree completely & 86 & 54,1 & 54,1 & 54,1 \\
\hline & I agree & 43 & 27,0 & 27,0 & 81,1 \\
\hline & I do not know & 21 & 13,2 & 13,2 & 94,3 \\
\hline & I disagree & 7 & 4,4 & 4,4 & 98,7 \\
\hline & I disagree completely & 2 & 1,3 & 1,3 & 100,0 \\
\hline & Total & 159 & 100,0 & 100,0 & \\
\hline
\end{tabular}


It is appreciated in table 9 that most of the students demonstrate a positive attitude towards the use of the second language when the teacher is explaining the lesson. This is a positive result because English is a language of communication and within the bilingual the program is necessary to teach at least $50-70 \%$ of the lessons in English.

\section{Table 10}

Valid percentage questionnaires' results, question 7

"Learning science subjects through English is beneficial for us".

\begin{tabular}{lllll}
\hline & & & Valid & Accumulated \\
& Frequency & Percentage & percentage & percentage \\
\hline Valid I agree completely & 84 & 52,8 & 52,8 & 52,8 \\
I agree & 41 & 25,8 & 25,8 & 78,6 \\
I do not know & 16 & 10,1 & 10,1 & 88,7 \\
I disagree & 7 & 4,4 & 4,4 & 93,1 \\
I disagree completely & 11 & 6,9 & 6,9 & 100,0 \\
Total & 159 & 100,0 & 100,0 & \\
\hline
\end{tabular}

Furthermore, in table 10, the item of "learning science subjects through English is beneficial for us", most of students agree completely (52'8\%) or agree $\left(25^{\prime} 8 \%\right)$ with that statement. This is a positive result concerning attitude and motivation as well as the bilingual program. They value the opportunity of learning science subjects through English. The results concerning the ability of students to learn in English (table 11) show that most of them $(36,5 \%$ and $22,6 \%)$ agree. This aspect is related to attitude because it shows that the students enjoy the lessons and, consequently, their attitude is positive. 


\section{Calderón Jurado \& Morilla García - Bilingual Education}

Table 11

Valid percentage questionnaires' results, question 8

"Bilingual lessons are accessible to everybody".

Valid

Accumulated

Frequency Percentage percentage percentage

\begin{tabular}{|c|c|c|c|c|c|}
\hline \multirow[t]{6}{*}{ Valid } & I agree completely & 58 & 36,5 & 36,5 & 36,5 \\
\hline & I agree & 36 & 22,6 & 22,6 & 59,1 \\
\hline & I do not know & 28 & 17,6 & 17,6 & 76,7 \\
\hline & I disagree & 12 & 7,5 & 7,5 & 84,3 \\
\hline & I disagree completely & 25 & 15,7 & 15,7 & 100,0 \\
\hline & Total & 159 & 100,0 & 100,0 & \\
\hline
\end{tabular}

The third dimension is related to the third research question of the study, dealing with the assessment of students about learning English in subjects such as sciences.

Results in table 12 indicate that, although learners feel shy when they have to speak in front of the class not using their mother tongue, they enjoy participating in lessons $(53,3 \%)$. That is, despite feeling embarrassed using it, they are able to use the lingua franca, which is desirable because they are communicating in English. Tables 13 and 14 show that 60,4\% and 47,7\% of students are highly motivated about learning English. This is a significant result, Gardner (1985, p.10) described that if students show desire when doing an activity, they will have a satisfactory experience that is relevant for language learning. 
Table 12

Valid percentage questionnaires' results, question 9

"Students are pleased with using the second language among peers and the teacher".

\begin{tabular}{llllll}
\hline & & & $\begin{array}{c}\text { Valid } \\
\text { Frequency }\end{array}$ & $\begin{array}{l}\text { Accumulated } \\
\text { Percentage }\end{array}$ \\
\hline Valid & I agree completely & 85 & 53,5 & 53,5 & 53,5 \\
& 27 & 17,0 & 17,0 & 70,4 \\
& I agree & 29 & 18,2 & 18,2 & 88,7 \\
I do not know & 6 & 3,8 & 3,8 & 92,5 \\
I disagree & 12 & 7,5 & 7,5 & 100,0 \\
I disagree completely & 159 & 100,0 & 100,0 & \\
Total & & &
\end{tabular}

Table 13

Valid percentage questionnaires' results, question 10

"Students really appreciate bilingual lessons"

\begin{tabular}{llllll}
\hline & & & $\begin{array}{c}\text { Valid } \\
\text { Frequency }\end{array}$ & $\begin{array}{l}\text { Accumulated } \\
\text { percentage }\end{array}$ \\
\hline Valid & I agree completely & 96 & 60,4 & 60,4 & 60,4 \\
& I agree & 36 & 22,6 & 22,6 & 83,0 \\
I do not know & 18 & 11,3 & 11,3 & 94,3 \\
I disagree & 5 & 3,1 & 3,1 & 97,5 \\
I disagree completely & 4 & 2,5 & 2,5 & 100,0 \\
Total & 159 & 100,0 & 100,0 & \\
\hline
\end{tabular}




\section{Calderón Jurado \& Morilla García - Bilingual Education}

Table 14

Valid percentage questionnaires' results, question 11

"Students wait enthusiastically for bilingual lessons"

\begin{tabular}{|c|c|c|c|c|c|}
\hline & & Frequency & Percentage & $\begin{array}{l}\text { Valid } \\
\text { percentage }\end{array}$ & $\begin{array}{l}\text { Accumulated } \\
\text { percentage }\end{array}$ \\
\hline \multirow[t]{6}{*}{ Valid } & I agree completely & 76 & 47,8 & 47,8 & 47,8 \\
\hline & I agree & 30 & 18,9 & 18,9 & 66,7 \\
\hline & I do not know & 30 & 18,9 & 18,9 & 85,5 \\
\hline & I disagree & 7 & 4,4 & 4,4 & 89,9 \\
\hline & I disagree completely & 16 & 10,1 & 10,1 & 100,0 \\
\hline & Total & 159 & 100,0 & 100,0 & \\
\hline
\end{tabular}

Table 15

Valid percentage questionnaires' results, question 12

"Learners would like to have more subjects within the bilingual program".

\begin{tabular}{lllll}
\hline & & & Valid & Accumulated \\
& Frequency & Percentage & percentage & percentage \\
\hline Valid I agree completely & 52 & 32,7 & 32,7 & 32,7 \\
I agree & 25 & 15,7 & 15,7 & 48,4 \\
I do not know & 17 & 10,7 & 10,7 & 59,1 \\
I disagree & 18 & 11,3 & 11,3 & 70,4 \\
I disagree completely & 47 & 29,6 & 29,6 & 100,0 \\
Total & 159 & 100,0 & 100,0 & \\
\hline
\end{tabular}

Moreover, as we can appreciate in table 15, 32,7\% of the students disagree completely with this statement. This can be produced by two factors. On the one hand, we have to take into account the level of difficulty of the subjects, it might be more complicated to learn concepts in the foreign language. The second factor is related to the quantity of subjects offered inside the bilingual program. For instance, CEIP 14001682 includes physical education, music and science in its bilingual program; results in table 16 indicate that $61,6 \%$ of students completely agree; they consider English useful as a valuable tool 
for the future, and, this idea has a positive effect on their attitude and motivation.

Table 16

Valid percentage questionnaires' results, question 13

"Students approve learning science subjects within the bilingual program"

\begin{tabular}{llllll}
\hline & & & Valid & Accumulated \\
Valid & I agree completely & 98 & 61,6 & 61,6 & 61,6 \\
& 21 & 13,2 & 13,2 & 74,8 \\
& I agree & 18 & 11,3 & 11,3 & 86,2 \\
& I do not know & 6 & 3,8 & 3,8 & 89,9 \\
I disagree & 16 & 10,1 & 10,1 & 100,0 \\
I disagree completely & 16 & 100,0 & 100,0 & \\
Total & 159 & &
\end{tabular}

Lastly, concerning the role of the families, the analysis in table 17 shows that $68,8 \%$ of the children agrees completely. This implies motivation on the part of both parents and students and that they consider English a useful tool for the future.

Table 17

Valid percentage questionnaires' results, question 14

"Students' families value the opportunity to learn English through the bilingual program".

\begin{tabular}{llllll}
\hline & & & $\begin{array}{c}\text { Valid } \\
\text { Frequency }\end{array}$ & $\begin{array}{l}\text { Accumulated } \\
\text { percentage }\end{array}$ \\
\hline Valid & I agree completely & 109 & 68,6 & 68,6 & 68,6 \\
& I agree & 18 & 11,3 & 11,3 & 79,9 \\
& I do not know & 25 & 15,7 & 15,7 & 95,6 \\
& I disagree & 2 & 1,3 & 1,3 & 96,9 \\
I disagree completely & 5 & 3,1 & 3,1 & 100,0 \\
Total & 159 & 100,0 & 100,0 & \\
\hline
\end{tabular}


The last dimension that is analyzed concerns "the use of the second language in the classroom". The results obtained respond to the fourth research question of our study. As can be observed in table 18, understanding the teacher using the second language, generates varied results. Some students $(25,5 \%)$ agree completely with that affirmation, whereas others $(27 \%)$, disagree completely. However, it is advisable to help students to feel comfortable with the second language and make use of it. Likewise, the obtained results in table 19 show that $85,5 \%$ of the students feel grateful for having a teaching assistant at school: they can help students to promote English as a medium of communication.

Table 18

Valid percentage questionnaires' results, question 15

"Students feel weak when they are unable to understand contents which are explained in the second language".

\begin{tabular}{llllll}
\hline & & & Valid & Accumulated \\
Valid & I agree completely & 40 & 25,2 & 25,2 & 25,2 \\
& I agree & 26 & 16,4 & 16,4 & 41,5 \\
& I do not know & 27 & 17,0 & 17,0 & 58,5 \\
& I disagree & 23 & 14,5 & 14,5 & 73,0 \\
& I disagree completely & 43 & 27,0 & 27,0 & 100,0 \\
& Total & 159 & 100,0 & 100,0 & \\
\hline
\end{tabular}

Table 19

Valid percentage questionnaires' results, question 16

"Students appreciate the role of the teaching assistant in the lessons".

\begin{tabular}{|c|c|c|c|c|c|}
\hline & & Frequency & Percentage & $\begin{array}{l}\text { Valid } \\
\text { percentage }\end{array}$ & $\begin{array}{l}\text { Accumulated } \\
\text { percentage }\end{array}$ \\
\hline \multirow[t]{6}{*}{$\overline{\text { Valid }}$} & I agree completely & 128 & 80,5 & 80,5 & 80,5 \\
\hline & I agree & 14 & 8,8 & 8,8 & 89,3 \\
\hline & I do not know & 11 & 6,9 & 6,9 & 96,2 \\
\hline & I disagree & 1 & ,6 & ,6 & 96,9 \\
\hline & I disagree completely & 5 & 3,1 & 3,1 & 100,0 \\
\hline & Total & 159 & 100,0 & 100,0 & \\
\hline
\end{tabular}


Aside from this, assistant teachers can introduce learners to their culture and by doing so students can gain knowledge about some typical customs of the country of the second language. Finally, results in table 20 shows that, although students like learning science through the L2, they feel shy when it comes to taking part in the bilingual lesson. That is a negative aspect of the bilingual program that needs to be tackled, perhaps by building greater cooperation between teachers and pupils.

Table 20

Valid percentage questionnaires' results, question 17

"Students feel shy participating on bilingual lessons".

\begin{tabular}{llllll}
\hline & & & Valid & Accumulated \\
Valid & I agree completely & 43 & 27,0 & 27,0 & 27,0 \\
& I agree & 19 & 11,9 & 11,9 & 39,0 \\
& I do not know & 17 & 10,7 & 10,7 & 49,7 \\
I disagree & 17 & 10,7 & 10,7 & 60,4 \\
I disagree completely & 63 & 39,6 & 39,6 & 100,0 \\
Total & 159 & 100,0 & 100,0 & \\
\hline
\end{tabular}

As a global result, it can be contended that the bilingual program improves students' attitude and motivation. Learners feel satisfaction when they are learning sciences through English because they know they own the possibility to improve their English quality apart from being English an opportunity for their future career. However, sometimes, when the teacher makes use of the second language in the classroom, they hesitate about their answers. It is relevant to make students feel restored and help them when using the second language.

Furthermore, a comparison between both schools has been carried out taking into account students from the $3^{\text {rd }}$ and $4^{\text {th }}$ years. The following figures show the results of this comparison: 


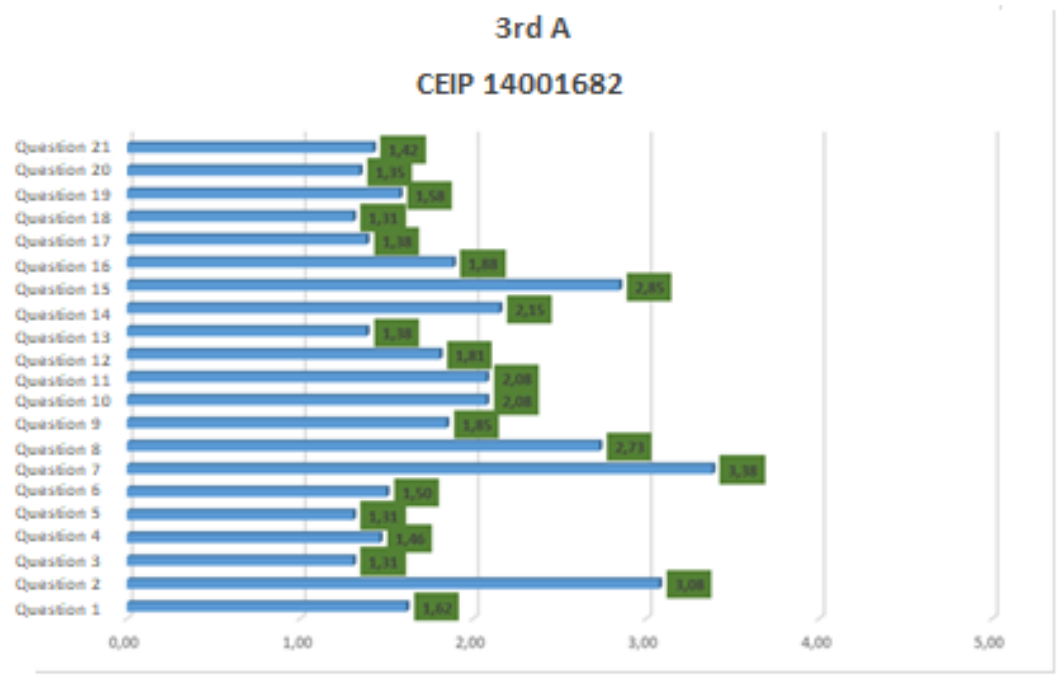

Figure 1. Average questionnaires' results $3^{\text {rd }}$ A CEIP 14001682

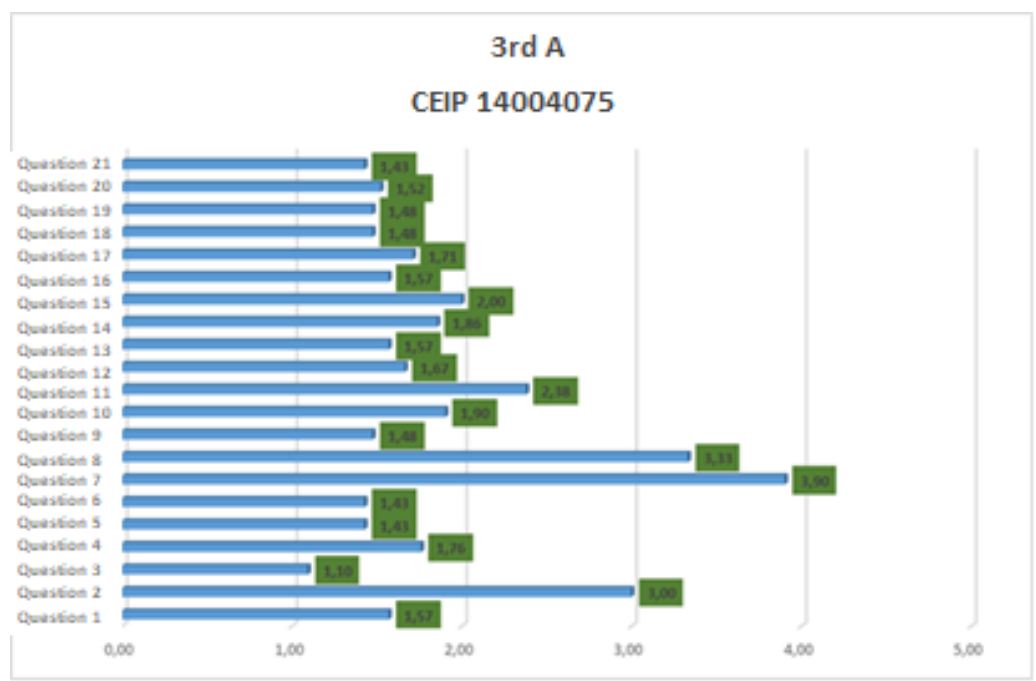

Figure 2. Average questionnaires' results $3^{\text {rd }}$ A CEIP 14004075 


\section{IJEP - International Journal of Educational Psychology, 7(3) 335}

According to the data gathered, the figures above represent the average answers for each question from the questionnaire. Firstly, in 3rd year students from the CEIP 14001682 (see figure 1), the majority of answers were positive, with the most chosen answers being "I completely agree" and "I agree", as can be observed in the diagram. Regarding 3rd year students from the CEIP 14004075 (see figure 2), most of the results are also positive, with the answers "I completely agree" and "I agree" appearing in response to most of the questions. However, with question number 7 "I do not like when the teacher speaks English in the classroom", children hesitate about the answer in both institutions, and most of them choose number 3 "I do not know". Then, in question number 8, "I feel shy when I have to take part in the English lesson", students from CEIP 14001682 nearly agree whereas students from CEIP 14004075 do not know. Finally, question number 15, related to intrinsic motivation, "I would like to have more subjects in which English is spoken", learners from CEIP 14001682, are close to "I do not know", while children from CEIP 14004075 agree. This may be due to the quantity of subjects offered in each bilingual school.

These results, which are reflected in figures 1 and 2 respectively, are positive. Nevertheless, students have some problems when the teacher uses the L2 in the classroom and when they need to use it. Moreover, it is important that students feel comfortable in the lessons, as well as using the second language. In this case, the role of emotional intelligence is relevant. According to Pavón and Ávila (2009, p. 91), emotional intelligence is essential for the acquisition of the L2: it helps to develop the student's own abilities and enables them to interact within the classroom.

When focusing on students from $4^{\text {th }}$ year (see figure 3 and figure 4 ), in question number 2, "If I do not understand something that my teacher has explained in English I feel weak", nearly all students from CEIP 14001682 answered "do not know", and, students from CEIP 14004075 are close to disagree. If we focus on question number 4 , in both institutions there is a positive result towards learning English in subjects such as science. However, in question number 7 "I do not like when the teacher speaks English in the lesson", students from both schools hesitate. Nevertheless, the $4^{\text {th }}$ year group from CEIP 14001682, seems to be more confident when the teacher speaks the second language in the classroom. Question 12 "I really like to take part in lessons in which English is spoken because I feel comfortable with my peers and my teacher", students from CEIP 14001682 
agree, although students from CEIP 14004075 "do not know". This difference may be a product of the number of years spent within the bilingual program in each school. Following with question number 14, in both schools, children wait for lessons enthusiastically, meaning that they exhibit positive motivation.

Finally, in question number 15 "I would like to have more subjects in which the English language is spoken" in both primary schools the result is close to "I do not know", however in the CEIP 14004075, children seem more in favour of having more subjects; currently, they only study science within the bilingual program. According to this analysis, attitude and motivation are favourable among the two groups. It has been demonstrated that attitude and motivation bear an influence on the acquisition of a foreign language. What's more, if these two affective factors are high, students' English will improve because attitude and motivation are related to how students feel and behave.

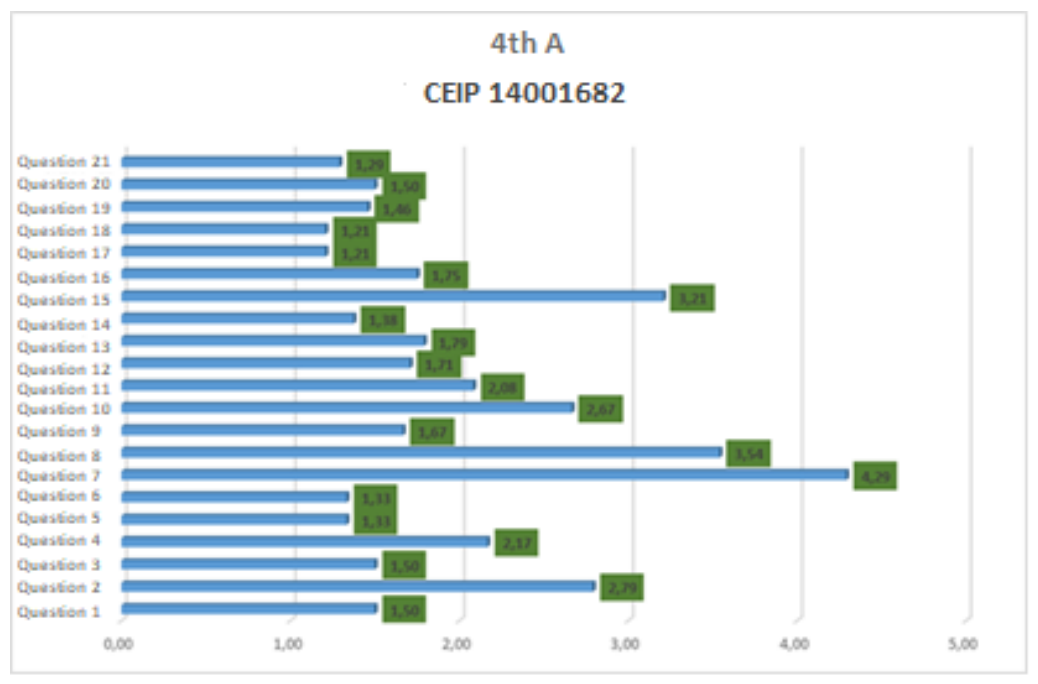

Figure 3. Average questionnaires' results $4^{\text {th }}$ A CEIP 14001682 


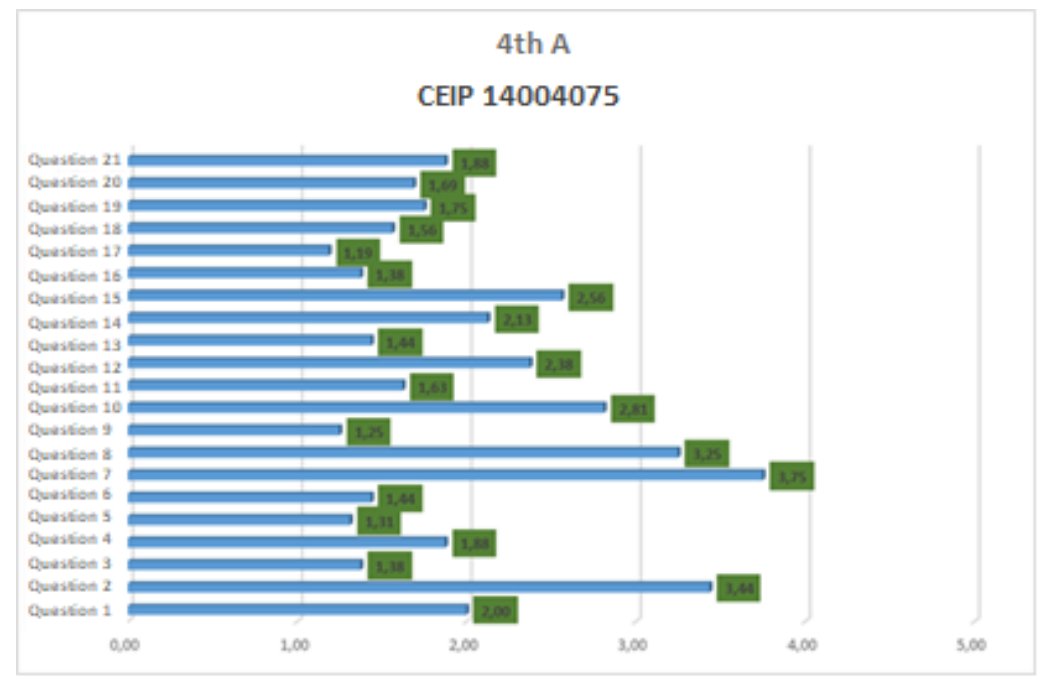

Figure 4. Average questionnaires' results $4^{\text {th }}$ A CEIP 14004075

\section{Discussion and Conclusion}

The aim of this study is to investigate several aspects regarding the acquisition of a foreign language, especially the attitude and motivation of primary school students towards science subjects within the bilingual program. It has been analysed through a questionnaire. Referring to the research questions, students feel motivated and also have a positive attitude towards the bilingual program at school. Likewise, they value learning different subjects through English due to their future possibilities. However, sometimes, it is complicated for them to understand the teacher using the L2. As it can be observed in Q1, some students have problems when using the L2. It is advisable to make students feel comfortable listening and speaking to the foreign language; they need to be confident when doing so. However, referring to Q4, although they got some problems understanding the L2, the majority of students show a great interest in learning English. This result reveals that attitude is decisive and is related to the interest of the students in acquiring a second language. Focusing on the role of the parents, as Q20 reveals, they are a great support, which makes students feel confident 


\section{Calderón Jurado \& Morilla García - Bilingual Education}

learning English. According to Kara (2009), attitude has a key influence on language learning acquisition as well as on the students' behaviour.

The results show that attitude and motivation towards the bilingual program at school are high. Having an assertive attitude implies great efficiency when learning English, due to the fact that students' behaviour and attitude are related to language learning (Kara, 2009). However, question number 8 "I feel shy when I have to take part in the lesson" is a negative result which needs to be tackled because English is a language for communication.

Respectively, the number of subjects offered in CEIP 14001682 (science, music and physical education) may have had an influence on these answers, as more bilingual subjects are offered here compared to the CEIP 14004075 (science). Moreover, attention to diversity should also be considered: not all students have the same level of English. In relation to the comparison between the institutions and the subjects which are offered by them, the most relevant aspect can be found in question number 8, where students hesitate when the teacher uses the target language. Additionally, if a comparison is made among the four classes, it can be said that the results are similar among all classes. In question number 15 all learners hesitate. These questions refer to the use of the second language on the part of the teacher and teaching more subjects within the bilingual program at school. Nevertheless, students from the CEIP 14004075 seem to be more in favour of having more subjects within the bilingual program. In light of the results, once again, dealing with attention to diversity is a must in order to solve this dilemma.

With regards to the research question about the motivation of students towards the bilingual program at school, it can be said that they feel motivated: not only due to the fact that they enjoy lessons and eagerly wait for them, but also because they want to learn English as they think it is useful for their future. Secondly, when focusing on the bilingual program in relation to the improvement of their attitude towards English, it should be noted that the bilingual program is helping with this issue: it is improving their attitude towards English because they are constantly working with English and this makes the children happy. Nevertheless, the existence of too great a number of subjects in English can affect their attitude negatively. Thirdly, when students are asked about the importance of learning English, the answer is positive as they view learning English as significant. They value English as a useful tool for the future. However, students do not feel 
entirely confident when they are not able to understand some concepts in the second language. They sometimes need the teacher to repeat the concepts in Spanish. The results show that students "agree completely" or "agree" with the questions.

Similarly, Dörnyey (1998) argued that motivation affects the success of learners. In order to maintain positive attitudes and motivation among students, the support of the mentor is important. Another suitable pedagogical support is scaffolding. According to David Wood (1988) scaffolding is behaviour intended to tutor, which is contingent, collaborative and interactive. In addition, it is important to consider the different pace of learning and diversity of students (p.96). In light of these considerations, we should be aware of the fact that students' progress might be improved by promoting cooperative or group work and by using ICT (Information and Communications Technology). Some researchers (Gere, 1987; Lawrence \& Sommers, 1996; Nystrand, Gamoran, \& Heck, 1993) support the assumption that relying on peers and only receiving feedback from teachers creates autonomy in students and independence from teachers, as well as facilitating the deep cognitive processing of the contents they are dealing with.

On the basis of the results, students demonstrate a positive attitude and motivation towards science subjects within the bilingual program. The findings also show that paying attention to diversity is an essential factor that requires more attention. Further research is needed in order to take account of diversity in non-linguistic programmes in order to improve the understanding of language attainment in bilingual programs.

\section{References}

Broughton, G., Brumfit, C., Pincas, A., \& Wilde, R. D. (2002). Teaching English as a Foreign Language. Routledge Education Books.

Campbell, D. J., \& Stanley, J. C. (1963). Experimental and quasiexperimental designs for research on teaching. In N.L. Gage (Ed.), Handbook of Research on Teaching. Chicago: Rand McNally.

Coyle, D. (2010). Foreword. In D. Lasagabaster and Y. Ruiz de Zarobe (Eds.), CLIL in Spain: Implementation, results and teacher training (pp. vii-viii). Newcastle upon Tyne: Cambridge Scholars. 
Deci, E. L., \& Ryan, R. M. (1985). Intrinsic Motivation and SelfDetermination in Human Behavior. New York: Plenum Publishing Co.

Dörnyei, Z. (1998). Motivation in second and foreign language learning.
Language
Teaching,
$31(03)$,
117-135.
doi:
$10.1017 / \mathrm{s} 026144480001315 \mathrm{x}$

García, O. (2009). Bilingual Education in the 21st Century: A Global Perspective. West Sussex, UK: Wiley-Blackwell.

Gardner, R. (1985). Social psychology and second language learning. The role of attitudes and motivation. London: Edward Arnold.

Gardner, R., \& Lambert, W. (1972). Attitudes and motivation in second language learning. Rowley, MA: Newbury House.

Gere, A. (1987). Writing groups: History, theory, and implications. Carbondale: Southern Illinois University Press.

Kara, A. (2009). The Effect of a 'Learning Theories' Unit on Students' Attitudes towards Learning. Australian Journal of Teacher Education, 34(3), 100-113. doi: 10.14221/ajte.2009v34n3.5

Latchanna, G., \& Dagnew, A. (2009). Attitude of teachers towards the use of active learning methods. E-journal of All India Association for Educational Research, 21(1).

Lawrence, S., \& Sommers, E. (1996). From the park bench to the (writing) workshop table: Encouraging collaboration among inexperienced writers. Teaching English in the Two-Year College, 23, 101-111.

Lennartsson, F. (2008). Students' motivation and attitudes towards learning a second language: British and Swedish students' points of view. Retrieved from http://urn.kb.se/resolve?urn=urn:nbn:se:vxu:diva2571.

Maljers, A., Marsh, D., \& Wolff, D. (Eds.). (2007). Windows on CLIL: Content and Language Integrated Learning in the European Spotlight. The Hague: European Platform for Dutch Education.

Mehisto, P. (2012). Excellence in bilingual education: A guide for school principals. Cambridge: Cambridge University Press.

Montano, D. E., \& Kasprzyk, D. (2008). Theory of reasoned action, theory of planned behaviour, and the integrated behavioural model. In $\mathrm{K}$. Glanz, B. Rimer \& K. Viswanath (Eds.), Health behavior and health education: Theory, research, and practice (pp. 67-96). San Francisco, CA: Jossey-Bass. 
Noels, K. A. (2001). Learning Spanish as a second language: Learners' orientations and perceptions of their teachers' communication style. Language Learning, 51, 107-144.

Noels, K. A., Pelletier, L. G., Clément, R., \& Vallerand, R. J. (2003). Why are you learning a second language? Motivational orientations and self-determination theory. Language Learning, 50, 57-85. https://doi.org/10.1111/1467-9922.53223

Nystrand, M., Gamoran, A., \& Heck, M. (1993). Using small groups for response to and thinking about literature. English Journal, 82, 14-22. doi: $10.2307 / 820670$

Pavón, V., \& Ávila, J. (Eds.). (2009). Aplicaciones didácticas para la enseñanza integrada de lengua y contenidos (AICLE/CLIL/ÉMILE). Sevilla: Consejería de Educación de la Junta de AndalucíaUniversidad de Córdoba.

Pérez-Cañado, M. L. (2012). CLIL research in Europe: Past, present, and future. International Journal of Bilingual Education and Bilingualism, 15(3), 315-341. doi:10.1080/13670050.2011.630064

Pérez-Paredes, P., y Martínez-Sánchez, F. (2000-2001). A Spanish version of the foreign language classroom anxiety scale: Revisiting Aida's factor analysis. Revista Española de Lingüística Aplicada RESLA, 14, 337-352.

Reid, N. (2003). Getting started in pedagogical research in the physical sciences. Hull: LTSN Physical Sciences Centre, University of Hull.

Victori, M., \& Lockhart, W. (1995). Enhancing metacognition in selfdirected language learning. System, 23, 223-234. http://dx.doi.org/10.1016/0346-251X(95)00010-H

Wood, D. J. (1988). How Children Think and Learn. Oxford: Blackwell. 
Beatriz Calderón Jurado is graduated in the Master's Degree in Advanced English Studies (Cognitive Linguistics/Literature) and Bilingual Education. University of Córdoba, Spain.

Cristina Morilla García is Lecturer in the Department of English and German Philology, University of Cordoba, Spain.

Contact Address: Department of English and German Philology, University of Cordoba, Plaza Cardenal Salazar, 3 Facultad de Filosofía y Letras, Córdoba, Spain. Email: cristmogar@hotmail.com 